Scientific note - Znanstvena nota

UDK: 577.18

\title{
Determination of benzimidazole residues and their metabolites in raw milk using high performance liquid chromatography-diode array detection
}

\author{
doi: $10.15567 /$ mljekarstvo.2017.0308 \\ Marija Denžić Lugomer $^{1 *}$, Damir Pavliček ${ }^{1}$, Nina Bilandžić ${ }^{2}$ Darko Majnarić1 \\ ${ }^{1}$ Croatian Veterinary Institute Zagreb, Veterinary Department Križevci, 48260 Križevci, Croatia \\ ${ }^{2}$ Laboratory for Residue Control, Department of Veterinary Public Health, \\ Croatian Veterinary Institute Zagreb, 10000 Zagreb, Croatia
}

Received - Prispjelo: 22.12.2016.

Accepted - Prihvaćeno: 25.05.2017.

\begin{abstract}
A new analytical method using high performance liquid chromatography-diode array detector (HPLC-DAD) was developed for the analysis of 18 benzimidazoles and their metabolites in milk. Samples were extracted with acetonitrile and $n$-hexane and purified by polymer cation exchange (PCX) solid phase extraction cartridges. LC separation was performed on Xbridge $\mathrm{C} 18$ with gradient elution using acetonitrile and ammonium acetate buffer. The DAD detection was set at 298, 312, 254 and $290 \mathrm{~nm}$. The method was validated according to the criteria of Commission Decision 2002/657/EC. The following validation parameters were set: accuracy (expressed as recovery) 31.7-137.6 \%, limit of decision (CC $\alpha$ ) 6.0-120.6 $\mu \mathrm{g} \mathrm{kg}^{-1}$, detection capability (CC $\left.\beta\right) 6.1-120.8 \mu \mathrm{g} \mathrm{kg}^{-1}$, limit of detection (LOD) 1-4 $\mu \mathrm{g} \mathrm{kg}^{-1}$, limit of quantification (LOQ) $4-18 \mu \mathrm{g} \mathrm{kg}^{-1}$, precision as CV 7.0-22.5\%, withinlaboratory reproducibility expressed as CV 8.8-30.6 \%. Finally, the developed method was applied to the analysis of collected milk samples. A total of 50 milk samples was analysed for benzimidazole residues. All obtained concentrations for all compounds were below the LOQ values.
\end{abstract}

Key words: benzimidazoles, milk, HPLC-DAD, validation

\section{Introduction}

Benzimidazoles are veterinary drugs widely used for the prevention and treatment of parasitic infections in agriculture and aquaculture, including food producing animals (Danaher, 2007). The extensive use of benzimidazoles in lactating animals could result in the presence of their residues in milk and dairy products, which is harmful to consumers owing to their teratogenic and embryotoxic properties (Chen et al., 2010.). To ensure human food safety, the European Union set a maximum residue limits (MRLs) in animal tissues for most benzimidazoles, though only albendazole, fenbendazole, triclabendazole and thiabendazole have MRL values in milk (EC, 2010; EC, 2012; EC, 2014). The marker residue of almost all the benzimidazoles is defined as the sum of a parent drug and/or its metabolites.
The extraction and purification of benzimidazole residues from milk poses a difficult challenge. At present, the majority of methods used for detection of benzimidazole residues from milk do not generally include the complete range of marker residues for each substance. For effective control, benzimidazole residues in foods, including milk, methods capable of detecting the complete range of marker residues should be applied. In recent years, liquid chromatography coupled with tandem mass spectrometry (LC-MS/MS) has found more widespread application in benzimidazole residue analysis, offering more sensitive detection and increased confidence in reporting results (De Ruyck et al., 2002; Jedziniak et al., 2009; Xia et al., 2010; Chen et al., 2011). However, mass instruments are still quite expensive 
and not readily available to chemists in most laboratories. HPLC is the most widely applied method to separate residues of benzimidazoles drugs. Although fluorescence is more sensitive and selective, the most widely applied detector is ultraviolet (UV) (Takeba et al., 2000; De Ruyck et al., 2000).

The development of methods that cover the complete number of marker residues or the most persistent or predominant metabolites is difficult. As a result, a number of important benzimidazole residues, such as triclabendazole (TCB) and its metabolites, are not included into multi-residue methods. To date, there is only one published multi-residue method that encompasses 11 benzimidazoles and 10 metabolites in milk using the HPLC-UV technique (Chen et al., 2010). Disadvantages of that method are the long analysis time for HPLC-UV, which takes $80 \mathrm{~min}$, and the fact that it does not include one of the triclabendazole metabolites - ketotriclabendazole. The aim of this study was to develop a HPLC multi-residue method with DAD detection for the determination of benzimidazole markers and their metabolites in milk. The developed method was applied to the analysis of real milk samples taken from dairy farms in Croatia.

\section{Experimental}

\section{Drugs and reagents}

Analytical standards of albendazole sulphoxide (ABZ-SO), albendazole sulphone $\left(\mathrm{ABZ}-\mathrm{SO}_{2}\right)$, albendazole-2-amino-sulphone (ABZ- $\left.\mathrm{NH}_{2}-\mathrm{SO}_{2}\right)$, hydroxy mebendazole (MBZ-OH), amino mebendazole $\left(\mathrm{MBZ}-\mathrm{NH}_{2}\right)$, triclabendazole sulphoxide (TCB-SO), triclabendazole sulphone $\left(\mathrm{TCB}-\mathrm{SO}_{2}\right)$, and ketotriclabendazole (KTCB) were purchased from Witega (Berlin, Germany). Mebendazole (MBZ), fenbendazole (FEBZ), fenbendazole sulphoxide (oxfendazole, OFZ), fenbendazole sulphone $\left(\mathrm{FEBZ}-\mathrm{SO}_{2}\right)$, thiabendazole (TBZ), 5-hydroxy thiabendazole (5-OH-TBZ), flubendazole (FLU), 2-aminoflubendazole (FLU-HMET), oxibendazole (OXI) and nocodazole (NOC) as the internal standard were purchased from Sigma Aldrich (St. Louis, MO, USA).

Chemicals of analytical grade including glacial acetic acid, ammonium acetate, ammonium hydroxide, hydrochloric acid, anhydrous sodium sulphate, dimethylsulfoxide (DMSO), n-hexane and ethanol were supplied from Kemika (Zagreb, Croatia). Acetonitrile and methanol were HPLC-grade and also obtained from Kemika (Zagreb, Croatia). Water was purified with a Millipore DirectQ5 UV system (Merck Millipore, USA).

The ammonium hydroxide-acetonitrile solution used for the eluation of analytes was prepared on the day of use by mixing $160 \mathrm{~mL}$ acetonitrile with $22 \mathrm{~mL}$ conc. ammonium hydroxide and making up to $200 \mathrm{~mL}$ with acetonitrile.

The cartridge used for solid phase extraction (SPE) was PLEXA PCX cartridge $(500 \mathrm{mg}, 6 \mathrm{~mL}$, Agilent, Milford, HA, USA).

Prior to HPLC injection, samples were filtered through a $0.45 \mu \mathrm{m}$ PTFE syringe filter from FilterBio (Nantong City, Jiangsu P.R China).

\section{Preparation of stock and working solutions}

Individual stock standard solutions $(1 \mathrm{mg} / \mathrm{mL})$ of all analytes were made by dissolving each standard in DMSO and stored at $-20{ }^{\circ} \mathrm{C}$ for 5 years.

For linearity testing, a mixed standard solution containing 20 or $50 \mu \mathrm{g} \mathrm{mL} \mathrm{m}^{-1}$ of all compounds was prepared by combining 200 or $500 \mu \mathrm{L}$ of each standard stock solution and diluting to $10 \mathrm{~mL}$ with ethanol. For other validation parameters study, a mixed standard solution containing 2.5 or $5 \mu \mathrm{g} \mathrm{mL}^{-1}$ was prepared. The solutions were stored at $-20{ }^{\circ} \mathrm{C}$ for 1 year. During these periods we have not observed any signs of decomposition of analytes. Standard working solutions, at various concentrations, were prepared daily by the appropriate dilution of the mixed standard solution with mobile phase A.

\section{Sample collection}

Cow milk samples were collected by authorized veterinarians at dairy farms in different regions of continental Croatia. In total, 50 milk samples were sampled in different counties: 7 in Zagreb County, 8 in Krapina Zagorje County, 8 in Karlovac County, 8 in Koprivnica Krizevci County, 6 in Brod Posavina County, 13 in Baranya County. Milk samples were collected in a polyethylene bottle of $50 \mathrm{~mL}$ volume. Samples were stored at $-20{ }^{\circ} \mathrm{C}$ until the time of analysis. Analysed milk samples that were found to contain no detectable residues of the analytes were used as the negative controls (blank). 


\section{Sample preparation}

A $10 \mathrm{~g}$ sample of milk was weighed into a $50 \mathrm{~mL}$ centrifuge tube and 2-3 g anhydrous sodium sulphate was added. The mixture was vortexed for $1 \mathrm{~min}$ and $10 \mathrm{~mL}$ acetonitrile was added. This mixture was shaken for $10 \mathrm{~min}$ and centrifuged for $15 \mathrm{~min}$ at $3600 \mathrm{rpm}$. The supernatant was decanted into another $50 \mathrm{~mL}$ centrifuge tube containing $10 \mathrm{~mL}$ water and $10 \mathrm{~mL} 0.1 \mathrm{M}$ hydrochloric acid. This mixture was washed with $10 \mathrm{~mL}$ hexane (shaken for $10 \mathrm{~min}$, centrifuged for $5 \mathrm{~min}$ at $3000 \mathrm{rpm}$ ), the hexane phase was discarded and the rest was diluted with water to $50 \mathrm{~mL}$.

The PCX cartridge was pre-conditioned with $5 \mathrm{~mL}$ methanol and $5 \mathrm{~mL}$ water. Entire extracts were loaded onto the SPE. The column was washed twice with $5 \mathrm{~mL} 0.1 \mathrm{M}$ hydrochloric acid and then with $5 \mathrm{~mL}$ methanol. The column was then dried by purging air at $600 \mathrm{mbar}$ for $10 \mathrm{~min}$. The analytes were eluted with $10 \mathrm{~mL}$ ammonium hydroxideacetonitrile solution, evaporated to dryness under nitrogen at $40{ }^{\circ} \mathrm{C}$ and redissolved in $40 \mu \mathrm{L}$ methanol, vortexed for $1 \mathrm{~min}$, with the addition of $160 \mu \mathrm{L}$ mobile phase $\mathrm{A}$, vortexed for $1 \mathrm{~min}$ and the solution was filtered before HPLC analysis.

\section{Instrumentation and chromatographic conditions}

Benzimdazole determination was performed using HPLC-DAD system comprising of 1260 degasser, 1260 dual pump system, 1290 autosampler, 1260 column oven and 1200 DAD detector (Agilent, Palo Alto, CA, USA). Gradient elution using column Xbridge C18 4.6 x 150 mm, $3.5 \mu$ m equipped with a guard column $3.5 \mu \mathrm{m}, 4.6 \times 20 \mathrm{~mm}$ was used for chromatographic separation (Waters Corp., Milford, MA, USA). The column temperature was maintained at $55{ }^{\circ} \mathrm{C}$ in gradient mode with buffer solution containing $0.01 \mathrm{M}$ ammonium acetate to pH 5.7 with $1 \%$ acetic acid as mobile phase A and acetonitrile as mobile phase $\mathrm{B}$. The gradient program was: 0 min $82 \%$ A, $20 \min 67 \%$ A, $25 \min 10 \%$ A, $26 \mathrm{~min} 82 \% \mathrm{~A}$. The flow rate during analysis was $1 \mathrm{~mL} / \mathrm{min}$. The injected volume was $50 \mu \mathrm{L}$ and the $\mathrm{DAD}$ analysis was performed monitoring four different wavelengths: 298, 312, 254 and $290 \mathrm{~nm}$ with scan the entire spectrum from 190 to $320 \mathrm{~nm}$.

\section{Method validation}

The developed method was validated according to procedures described in Commission Decision 2002/657/EC covering specificity, calibration curve linearity, precision, decision limit $\left(\mathrm{CC}_{\alpha}\right)$ and detection capability $\left(\mathrm{CC}_{\beta}\right)(\mathrm{EC}, 2002)$.

In order to determine validation parameters, different amounts (100, 200 or $300 \mu \mathrm{L})$ of working standard solution $\left(0.5\right.$ respectively $\left.5 \mu \mathrm{g} \mathrm{mL}^{-1}\right)$ were added to $10 \mathrm{~g}$ samples of bovine and ovine milk free from benzimidazoles. The samples were held at room temperature for $15 \mathrm{~min}$ prior to extraction ensuring absorption of the standard solution. The results of validation were calculated for individual substances.

Selectivity. To establish the selectivity/specificity of the method, milk samples fortified with the benzimidazoles at MRLs and at $5 \mu \mathrm{g} \mathrm{kg}^{-1}$ for substances without MRLs and non-fortified samples were analysed to verify the absence of interfering substances around the retention time of analytes

Linearity and quantitative analysis. Standard calibration curves were prepared with the injection of working standard solutions at six concentration levels from 0.125 to $4 \mu \mathrm{g} \mathrm{mL} \mathrm{m}^{-1}$ respectively from 0.3125 to $10 \mu \mathrm{g} \mathrm{mL}^{-1}$ and calculated using linear least squares regression analyses of the peak area to concentration ratios.

Precision and accuracy. To estimate the precision of the analytical method, blank milk samples were fortified with a standard working solution (0.5 respectively $5 \mu \mathrm{g} \mathrm{mL}^{-1}$ ) containing a mix of benzimidazoles at least three levels for substances with MRLs (5, 10 and $15 \mu \mathrm{g} \mathrm{kg}^{-1} ; 25,50,100$ and $\left.150 \mu \mathrm{g} \mathrm{kg}^{-1}\right)$ and at three levels for substances without MRLs (5, 10 and $15 \mu \mathrm{g} \mathrm{kg}^{-1}$ ) in six replicates for each concentration. The complete extraction and purification procedures were performed for the spiked samples. Within-laboratory reproducibility was determined by repeating the study on three consecutive days with two different analysts and different lots of chemicals. For each level, the average concentration, standard deviation (SD), coefficient of variation $(\mathrm{CV}, \%)$ and recovery were calculated. 
$\mathrm{CC}_{\alpha}$ and $\mathrm{CC}_{\beta}$. Decision limit $\left(\mathrm{CC}_{\alpha}\right)$ and detection capability $\left(\mathrm{CC}_{\beta}\right)$ were calculated using withinlaboratory reproducibility validation results, according to the equation:

- for substances with MRLs

$$
\begin{aligned}
& \mathrm{CC}_{\alpha}=\mathrm{MRL}+1.64 \times \mathrm{SD}_{\mathrm{WLR}} \\
& \mathrm{CC}_{\beta}=\mathrm{CC}_{\alpha}+1.64 \times \mathrm{SD}_{\mathrm{WLR}}
\end{aligned}
$$

MRL- concentration equal to MRL value; $\mathrm{SD}_{\mathrm{WLR}}$ - standard deviation of within-laboratory reproducibility,

- for substances without MRLs

$$
\begin{aligned}
& \mathrm{CC}_{\alpha}=\mathrm{c}_{0}+2.33 \times \mathrm{SD}_{\mathrm{WLR}, \mathrm{C} 0} \\
& \mathrm{CC}_{\beta}=\mathrm{CC}_{\alpha}+1.64 \times \mathrm{SD}_{\mathrm{WLR}, \mathrm{C} 0}
\end{aligned}
$$

$\mathrm{C}_{0}$ - concentration equal to the lowest spiking level; $\mathrm{SD}_{\mathrm{WLR}, \mathrm{C} 0}$ - standard deviation of within-laboratory reproducibility at $\mathrm{c}_{0}$

LOD and LOQ. Limit of detection (LOD) was calculated on the basis of the lowest concentration according to the equation:

$$
\begin{aligned}
& \mathrm{LOD}=\mathrm{SD}_{\mathrm{WLR}, \mathrm{C} 0} \times \mathrm{t}_{0,02} \\
& \mathrm{LOQ}=10 \times \mathrm{SD}_{\mathrm{WLR}, \mathrm{C} 0}
\end{aligned}
$$

$t_{0,02}$ - student $t$ value at $n-1$ degrees of freedom and probability of $98 \%$; $\mathrm{SD}_{\mathrm{WLR}, \mathrm{C} 0}$ - standard deviation of within-laboratory reproducibility at $\mathrm{c}_{0}$.

\section{Statistical analysis of data}

Statistical analysis of the results data of validation parameters was performed using the Microsoft Excel program. Calculated statistical values included the mean, standard deviation (SD) and coefficient of variation (CV \%). Results data were analysed with statistical method Anova Single Factor with level of significance $\mathrm{p}=0.05$.

\section{Results and discussion}

In this study, we were looking for a simple, fast and reliable method for the determination of benzimidazole drugs. Due to the great difference in chemical properties, it was difficult to develop a method to cover the entire range of benzimidazoles. Acetonitrile and ammonium acetate buffer were selected as the mobile phase according to Chen et al. (2010). The maximum sensitivity and satisfactory separation of all analytes was achieved when using $0.01 \mathrm{M}$ ammonium acetate $(\mathrm{pH} 5.7$ with $1 \%$ acetic acid). The gradient was optimized to provide the maximum separation possible in minimum time period. The biggest challenge was to separate all triclabendazole metabolites, since they elute very closely. Column temperature, in addition to the concentration of acetonitrile in the mobile phase, proved to be an important separation factor.

No interfering peaks were observed for the retention time for benzimidazoles, except for the retention times for the triclabendazole metabolites and FEBZ$\mathrm{SO}_{2}$ (Fig. 1) where an interfering peak of negligible size, relative to MRL concentration, were observed.

The linearity of standard calibration curves was acceptable and within the range from 0.125 to $4 \mu \mathrm{g}$ $\mathrm{mL}^{-1}$ respectively from 0.3125 to $10 \mu \mathrm{g} \mathrm{mL}^{-1}$ and values of R2 for all anaytes were above 0.99 .

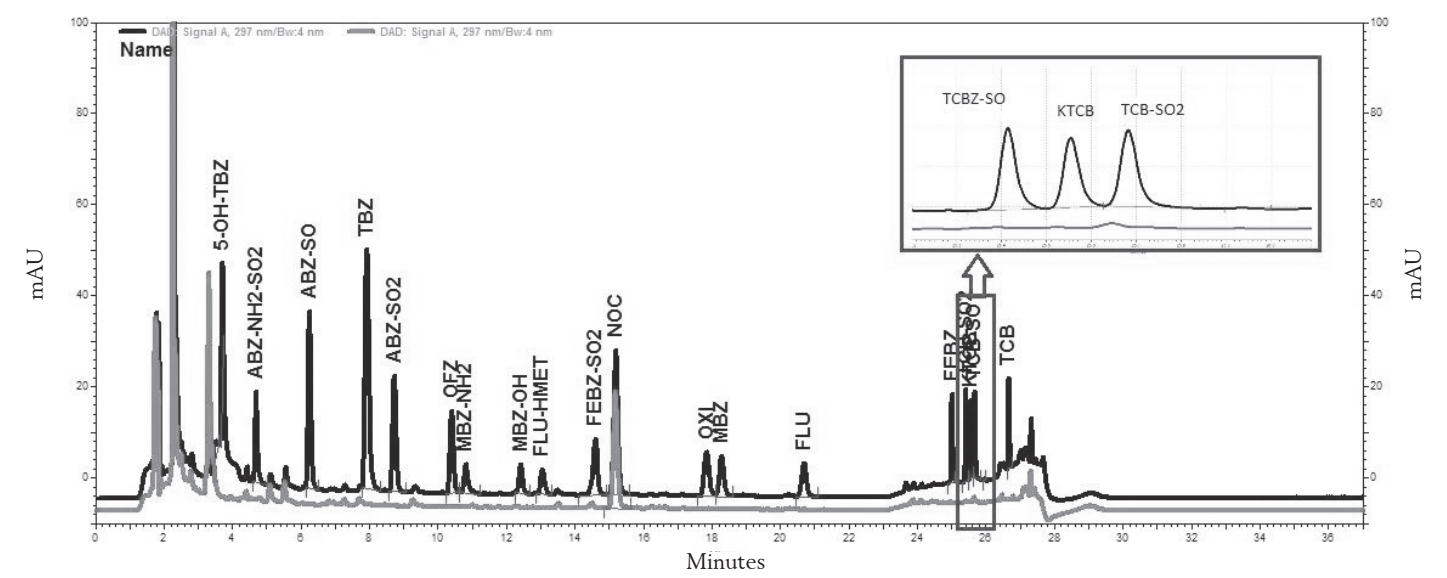

Figure 1. LC-UV chromatograms at $297 \mathrm{~nm}$ of blank milk (gray) and spiked with benzimidazoles at MRLs and $\mathrm{c}_{0}$ concentrations (black) 
Mean recoveries $(n=6)$ of the analytes, determined in six separate assays, were between $60 \%$ and $100 \%$ (Table 1). Lower mean recoveries of approximately $30 \%$ were obtained for KTCB and TCB-SO $\mathrm{S}_{2}$, higher mean recoveries of approximately $120 \%$ were obtained for $\mathrm{ABZ}-\mathrm{SO}_{2}$ and $135 \%$ FEBZ-SO ${ }_{2}$. These obtainedvalues were not acceptable according to Commission Decision 2002/657/EC, but since the statistical analysis ANOVA showed no differences among the results, and because of comparability with the results of other studies, obtained results were accepted in that kind with obligatory correction when expression results. The procedure did not prevent the oxidation of benzimidazoles. This is especially notable in the case of high recoveries of FEBZ-SO $\mathrm{S}_{2}$. Similar low values for recoveries (21-33\%) and low precision of determination (CV 22-34 \%) of FEBZ together with high recoveries of FEBZ-SO and FEBZ-SO, were found in study of Jedziniak et al. (2009). The authors described sample preparation as extracting analytes from an alkalized matrix to ethyl acetate and then defatting the extract with hexane. To prevent the oxidation of benzimidazoles, two antioxidant agents were used. TCB metabolites were recovered at approximately 30-50 \%. Although authors used different methods of sample preparation comparing to our method, obtained similar validation results indicate further need to develop methods of sample preparation with the aim of better results for validation parameters of named analytes. Another possibility is expressing validation results for the sum of parent compounds and their metabolites which showed more reliable accuracy and precision than for individual substances (Jedziniak et al., 2009.). Danaher et al. (2007) indicated that TCBZ metabolites are in a neutral state at a lower $\mathrm{pH}$ than other benzimidazoles and that this can have an influence on the repeatability of the extraction of these compounds. In a similar study using liquid-liquid extraction, sample preparation with acetonitrile, with an additional solid-phase sample extraction step procedure, followed by quantification

Table 1. The validation results for parameter recovery, precision and within-laboratory reproducibility for benzimidazoles in milk

\begin{tabular}{|c|c|c|c|}
\hline Compound & Recovery*,\% & $\begin{array}{c}\text { Precision } \\
\mathrm{CV}(\%)^{*}, \mathrm{n}=6\end{array}$ & $\begin{array}{l}\text { Within-laboratory } \\
\text { reproducibility } \\
\text { CV }(\%)^{*}, n=36\end{array}$ \\
\hline 5-OH-TBZ & $68.0 \pm 5.3$ & $11.7 \pm 3.1$ & $9.5 \pm 1.8$ \\
\hline $\mathrm{ABZ}-\mathrm{NH}_{2}-\mathrm{SO}_{2}$ & $69.7 \pm 3.1$ & $7.6 \pm 5.7$ & $9.4 \pm 2.0$ \\
\hline ABZ-SO & $71.7 \pm 2.4$ & $7.0 \pm 5.6$ & $9.0 \pm 2.1$ \\
\hline TBZ & $76.5 \pm 7.4$ & $12.3 \pm 4.2$ & $10.4 \pm 3.7$ \\
\hline $\mathrm{ABZ}-\mathrm{SO}_{2}$ & $121.2 \pm 4.5$ & $7.0 \pm 5.4$ & $8.8 \pm 2.3$ \\
\hline OFZ & $97.0 \pm 8.5$ & $9.2 \pm 7.2$ & $13.1 \pm 2.5$ \\
\hline${\mathrm{MBZ}-\mathrm{NH}_{2}}_{2}$ & $62.8 \pm 4.9$ & $8.1 \pm 5.6$ & $13.6 \pm 0.3$ \\
\hline MBZ-OH & $73.2 \pm 7.3$ & $20.8 \pm 6.7$ & $20.8 \pm 4.6$ \\
\hline FLU-HMET & $101.4 \pm 31.0$ & $9.3 \pm 5.9$ & $16.8 \pm 2.6$ \\
\hline${\mathrm{FEBZ}-\mathrm{SO}_{2}}_{2}$ & $137.6 \pm 10.4$ & $7.5 \pm 5.5$ & $10.9 \pm 0.6$ \\
\hline OXI & $77.7 \pm 3.4$ & $7.2 \pm 5.1$ & $10.7 \pm 0.5$ \\
\hline MBZ & $85.4 \pm 8.1$ & $6.6 \pm 4.9$ & $10.5 \pm 1.4$ \\
\hline FLU & $83.0 \pm 1.5$ & $8.0 \pm 5.8$ & $14.3 \pm 1.5$ \\
\hline FEBZ & $67.6 \pm 11.3$ & $12.0 \pm 3.1$ & $19.1 \pm 7.4$ \\
\hline TCB-SO & $25.4 \pm 19.4$ & $17.0 \pm 6.0$ & $37.0 \pm 1.9$ \\
\hline KTCB & $31.7 \pm 7.3$ & $22.5 \pm 5.2$ & $29.4 \pm 9.4$ \\
\hline TCB-SO & $53.6 \pm 10.6$ & $11.2 \pm 2.8$ & $30.6 \pm 13.8$ \\
\hline ТCB & $69.5 \pm 19.9$ & $16.5 \pm 8.2$ & $24.2 \pm 9.5$ \\
\hline
\end{tabular}

${ }^{*}$ Average measured values $\pm \mathrm{SD}$ 
by HPLC-UV method, the recoveries were determined in the range from $78 \%$ to $109 \%$ (Chen et al., 2010). The reported method did not include the metabolite KTCB. To quantify the target analytes in milk, the authors used matrix-matched calibration curves within the range from 10 to $200 \mu \mathrm{g} \mathrm{kg}^{-1}$. The validated method described in this study covers the range from 2.5 to $200 \mu \mathrm{g} \mathrm{kg}^{-1}$, which is a much lower concentration range. In another study on the determination of anthelmintic compounds, including benzimidazole compounds, using the QuEChERS procedure for sample preparation and detection by UPLC-MS/MS, a recovery of 70-110\% was obtained (Whelan et al., 2010).

The results of accuracy and precision data are summarized in Table 1. For most analytes, CV\% values were less than $26 \%$. In some instances (TCB metabolites), $\mathrm{CV} \%$ values were in excess of $25 \%$. $\mathrm{CV}$ theoretical was calculated according to the Horowitz equation $\mathrm{CV} \%=2^{1-0,5 \log \mathrm{C}}$ and compared to the validation results data. In the case of not matching results data were analysed with the statistical method Anova Single Factor ( $p=0.05$ ), which found no significant differences among the results.
Chen et al. (2010) showed intermediate precision expressed as RSD \% in the range 4-16\%. Comparing all analyses, higher values were obtained for TCB and its metabolites. The data reported in that study were obtained in the analysis of the corresponding samples at 10, 50 and $100 \mu \mathrm{g} \mathrm{kg}^{-1}$, which was only partially comparable to the present study since validation results for substances without MRLs were obtained at lower concentrations: 5, 10 and $15 \mu \mathrm{g} \mathrm{kg}^{-1}$. In another study using the QuEChERS procedure for sample preparation, $\mathrm{CV} \%$ for repeatability was $>23 \%$ for TCB-SO, TCB-SO, and 5-OH-TBZ at low level validation (2, 3 and $4 \mu \mathrm{g} \mathrm{kg}^{-1}$ ) (Whelan et al., 2010).

In the present study, low values were obtained for LOD (1-4 $\left.\mu \mathrm{g} \mathrm{kg}^{-1}\right)$ and LOQ (4-18 $\left.\mu \mathrm{g} \mathrm{kg}^{-1}\right)$. Sensitivity of the method was far below the MRL levels. Chen et al. (2010) obtained a similar LOD and LOQ values of 3 and $10 \mu \mathrm{g} \mathrm{kg}^{-1}$ using HPLC-UV. However, in another study using ultra high performance liquid chromatography and tandem mass spectrometry (UHPLC-MS/MS), LOD values were much lower: 0.1-0.6 $\mu \mathrm{g} \mathrm{L} \mathrm{L}^{-1}$ (De Ruyck et al., 2002) and $<1 \mu \mathrm{g} \mathrm{kg}^{-1}$ (Whelan et al., 2010).

Table 2. Calculated parameters of $\mathrm{CC}_{\alpha}, \mathrm{CC}_{\beta}$, LOD and LOQ

\begin{tabular}{|c|c|c|c|c|}
\hline Compound & $\mathrm{CC}_{\alpha}\left(\mu \mathrm{g} \mathrm{kg}^{-1}\right)$ & $\mathrm{CC}_{\beta}\left(\mu \mathrm{g} \mathrm{kg}^{-1}\right)$ & $\operatorname{LOD}\left(\mu \mathrm{g} \mathrm{kg}^{-1}\right)$ & LOQ $\left(\mu \mathrm{g} \mathrm{kg}^{-1}\right)$ \\
\hline 5-OH-TBZ & 111.7 & 111.9 & 3.2 & 13.3 \\
\hline $\mathrm{ABZ}-\mathrm{NH}_{2}-\mathrm{SO}_{2}$ & 112.2 & 112.3 & 3.0 & 12.5 \\
\hline ABZ-SO & 112.2 & 112.4 & 2.7 & 11.2 \\
\hline TBZ & 116.3 & 116.6 & 2.6 & 10.8 \\
\hline $\mathrm{ABZ}-\mathrm{SO}_{2}$ & 120.6 & 120.8 & 4.3 & 17.7 \\
\hline OFZ & 12.3 & 14.6 & 1.8 & 7.6 \\
\hline${\mathrm{MBZ}-\mathrm{NH}_{2}}_{2}$ & 6.0 & 6.1 & 1.1 & 4.5 \\
\hline MBZ-OH & 6.7 & 6.8 & 1.8 & 7.5 \\
\hline FLU-HMET & 7.5 & 7.5 & 2.6 & 10.7 \\
\hline${\mathrm{FEBZ}-\mathrm{SO}_{2}}_{2}$ & 12.6 & 15.1 & 2.0 & 8.3 \\
\hline OXI & 6.0 & 6.0 & 1.1 & 4.4 \\
\hline MBZ & 6.2 & 6.2 & 1.3 & 5.2 \\
\hline FLU & 6.5 & 6.6 & 1.6 & 6.7 \\
\hline FEBZ & 12.3 & 14.5 & 1.1 & 4.4 \\
\hline TCB-SO & 12.4 & 12.5 & 1.1 & 4.5 \\
\hline KTCB & 12.8 & 12.9 & 1.5 & 6.0 \\
\hline TCB-SO & 14.8 & 14.9 & 1.2 & 4.7 \\
\hline TCB & 14.1 & 14.2 & 1.5 & 6.2 \\
\hline
\end{tabular}


The $\mathrm{CC}_{\alpha}$ and $\mathrm{CC}_{\beta}$ values are summarised in Table 2. Obviously, the highest percentile deviation on the target concentration was obtained for analytes without an MRL and analytes with a lower value of the MRL $\left(10 \mu \mathrm{g} \mathrm{kg}^{-1}\right)$. There are very few reported data on $\mathrm{CC}_{\alpha}$ and $\mathrm{CC}_{\beta}$ values. The $\mathrm{CC}_{\alpha}$ and $\mathrm{CC}_{\beta}$ values determined using UHPLC-MS/MS analysis were lower than those reported here, and ranged from 0.14 to 1.9 and 11 to $123 \mu \mathrm{g} \mathrm{kg}^{-1}$ for unapproved and MRL substances, respectively (Whelan et al., 2010).

\section{Application of the method}

The described analytical method was applied to real samples to assess the occurrence of anthelmintic drugs. In the present study, 50 samples of raw milk were collected in Croatia during 2014 and analysed. No detectable residues of the target analytes were found in any of these samples.

\section{Conclusions}

This paper reports the development and validation for a HPLC-DAD method for the simultaneous determination of following benzimidazoles and their metabolites: albendazole sulphoxide, albendazole sulphone, albendazole-2-amino-sulphone, hydroxy mebendazol, amino mebendazole, triclabendazole sulphoxide, triclabendazole sulphone, ketotriclabendazole, mebendazole, fenbendazole, fenbendazole sulphoxide, fenbendazole sulphone, thiabendazole, 5-hydroxy thiabendazole, flubendazole, 2-aminoflubendazole and oxibendazole. Benzimidazoles compounds were successfully separated by HPLC. The method has satisfactory validation characteristics according to Commission Decision 2002/657/EC for almost all analytes, except for KTCB, TCB-SO, FEBZ-SO $\mathrm{S}_{2}$ and $\mathrm{ABZ}-\mathrm{SO}_{2}$. Statistical analysis of the validation results have not observed any significant differences within results, so with obligatory correction of recovery when expressing results, method is suitable for the routine determination of benzimidazoles residues in milk. Further development of method in step of sample preparation in order to get a satisfactory validation parameters of listed analytes should be taken or validation for the sum of parent compounds and their metabolites should be carried out.

\section{Odredivanje ostataka benzimidazola $i$ njihovih metabolita u sirovom mlijeku u Hrvatskoj primjenom tekućinske kromatografije visoke djelotvornosti uz detektor s nizom dioda}

\section{Sažetak}

Razvijena je nova analitička metoda za određivanje 18 benzimidazola i njihovih metabolita $\mathrm{u}$ mlijeku primjenom tekućinske kromatografije visoke djelotvornosti uz detektor s nizom dioda (HPLC-DAD). Uzorci su ekstrahirani acetonitrilom i n-heksanom, te pročišćeni primjenom patrona punjenih polimernim kationskim izmjenjivačem (PCX). Kromatografska analiza provedena je na koloni Xbridge C18 uz gradijentu eluaciju acetonitrilom i amonijevo-acetatnim puferom. DAD detekcija praćena je na 298, 312, 254 i $290 \mathrm{~nm}$. Metoda je validirana u skladu s Odlukom Komisije 2002/657/EZ. Utvrđeni su sljedeći parametri validacije: točnost (izražena kao iskorištenje) 31,7-137,6 \%, granična koncentracija određivanja (CC $\alpha$ ) 6,0-120,6 $\mu \mathrm{g} \mathrm{kg}^{-1}$, sposobnost dokazivanja (CC $\beta$ ) 6,1-120,8 $\mathrm{g} \mathrm{kg} \mathrm{k}^{-1}$, granica određivanja (LOD) $1-4 \mu \mathrm{g} \mathrm{kg}^{-1}$, granica kvantifikacije (LOQ) 4-18 $\mu \mathrm{g} \mathrm{kg}^{-1}$, preciznost izražena kao CV 7,0-22,5 \%, unutar-laboratorijska reproducibilnost izražena kao CV 8,8-30,6 \%. Konačno, razvijena metoda primijenjena je za analizu prikupljenih uzoraka mlijeka. Ukupno 50 uzoraka mlijeka analizirano je na ostatke benzimidazolnih lijekova i njihovih metabolita. Sve koncentracije za sve analizirane spojeve ispod su LOQ vrijednosti.

Ključne riječi: benzimidazoli, mlijeko, HPLC-DAD, validacija 


\section{References}

1. Chen, D., Tao, Y., Liu, Z., Huang, L., Wang, Y., Pan, Y., Pend, D., Dai, M., Yuan, Z. (2010): Development of a high-performance liquid chromatography method to monitor the residues of benzimidazoles in bovine milk. Journal of Chromatography B 878, 2928-2932. http://doi.org/10.1016/j.chromb.2010.08.029

2. Chen, D., Tao, Y., Zhang, H., Pan, Y., Liu, Z., Huang, L., Wang, Y., Peng, D., Wang, X., Dai, M., Yuan, Z. (2011): Development of a liquid chromatography-tandem spectrometry with pressurized liquid extraction method for the determination of benzimidazole residues in edible tissues. Journal of Chromatography B 879, 1659-1667. http://doi.org/10.1016/j.chromb.2011.04.004

3. Danaher, M., De Ruyck, H., Crooks, S.R.H., Dowling, G., Keeffe, M.O. (2007): Review of methodology for the determination of benzimidazole residues in biological matrices. Journal of Chromatogaphy B 845,1-37. http://doi.org/10.1016/j.jchromb.2005.07.046

4. De Ruyck, H., Van Renterghem, R., De Ridder, H. De Brabander, D. (2000): Determination of anthelmintic residues in milk by high performance liquid chromatography. Food Control 11, 165-173.

5. De Ruyck, H., Daeseleire, E., De Ridder, H., Van Renterghem, R. (2002): Development and validation of a liquid chromatographic-electrospray tandem mass spectrometric multiresidue method for anthelmintics in milk. Journal of Chromatography A 976 (1-2), 181-194. http://doi.org/10.1016/S0021-9673(02)00936-6

6. European Commission. (2002): European Commission Decision 2002/657/EEC Implementing Council Directive 96/23/EC concerning the performance of analytical methods and the interpretation of results. Official Journal of the European Union L 221, 8-36.

7. European Commission. (2010): European Council Regulation 37/2010/EC of 22 December 2009 on pharmacologically active substances and their classification regarding maximum residue limits in foodstuffs of animal origin. Official Journal of the European Union L15, 1-72.
8. European Commission. (2012): Commission Implementing Regulation 1161/2012/EC of 7 December 2012 amending the Annex to Regulation (EU) No $37 / 2010$ on pharmacologically active substances and their classification regarding maximum residue limits in foodstuffs of animal origin, as regards the substance fenbendazole. Official Journal of the European Union L336, 14-16.

9. European Commission. (2014): Commission Implementing Regulation 676/2014/EC of 19 June 2014 amending Regulation (EU) No 37/2010, as regards the substance 'triclabendazole'. Official Journal of the European Union L180, 5-7.

10. Jedziniak, P., Szprengier-Juszkiewicz, T., Olejnik, M. (2009): Determination of benzimidazoles and levamisole residues in milk by liquid chromatography-mass spectrometry: Screening method development and validation. Journal of Chromatography A 1216, 8165-8172. http://doi.org/10.1016/j.chroma.2009.07.036

11. Takeba, K., Fujinuma, K., Sakamoto, M., Miyazaki, T., Oka, H., Itoh, Y., Nakazawa, H. (2000): Simultaneous determination of triclabendazole and its sulphoxide and sulphone metabolites in bovine milk by high-performance liquid chromatography. Journal of Chromatography A 882(1-2), 99-107. http://doi.org/10.1016/j.chroma.2010.05.007

12. Whelan, M., Kinsella, B., Furey, A., Moloney, M., Cantwell, H., Lehotay, S.J., Danaher, M. (2010): Determination of anthelmintic drug residues in milk using ultra high performance liquid chromatography-tandem mass spectrometry with rapid polarity switching. Journal of Chromatography A 1217, 4612-4622. http://doi.org/10.1021/jf102725b

13. Xia, X., Dong, Y., Luo, P., Wang, X., Li, X., Ding, S., Shen, J. (2010): Determination of benzimidazole residues in bovine milk by ultra-high performance liquid chromatography-tandem mass spectrometry. Journal of Chromatography B 878, 3174-3180. http://doi.org/10.1016/j.jchromb.2010.09.026 